\title{
IMPLEMENTASI SISTEM PENDIDIKAN NASIONAL DI PONDOK PESANTREN DARUL QURAN BANDUNG
}

\author{
Heti Aisah, Nurwadjah Ahmad E.Q., dan Andewi Suhartini \\ Prodi Pendidikan Islam, Konsentrasi Manajemen Pendidikan Islam \\ Program Doktoral UIN Sunan Gunung Djati Bandung \\ Email:mihyusalsha@gmail.com,nurwadjah.ahmad@gmail.com,dan \\ andewi.suhartini@uinsgd.ac.id
}

\begin{abstract}
Abstrak
Pesantren merupakan lembaga pendidikan keagamaan Islam yang memiliki Kyai, santri, pondok dan masjid. Lembaga pendidikan pesantren telah memberikan kontribusi besar dalam perannya memajukan dunia pendidikan di Indonesia. Artikel ini bertujuan untuk mengkaji peranan pesantren Darul Quran dalam menerapkan sistem pendidikan Nasional. Penelitian menggunakan metode penelitian kualitatif deskriftif, dengan teknik pengumpulan data melalui wawancara, studi dokumentasi dan observasi. Hasil penelitian menunjukkan bahwa pesantren Darul Quran Kota Bandung mampu menunjukkan perannya dalam sistem pendidikan Nasional, melalui Daqu method, dan Daili Activity yang mengantarkan para santrinya memiliki sikap, pengetahuan dan keterampilan dalam memenuhi kompetensi abad 21
\end{abstract}

Kata kunci: Peranan pondok pesantren, sistem pendidikan nasional, pondok pesantren

\begin{abstract}
Pesantren is an Islamic religious education institution that has Kyai, students, boarding schools and mosques. Pesantren education institutions have made a major contribution in their role in advancing the world of education in Indonesia. This article aims to examine the role of the Darul Quran Islamic boarding school in implementing the national education system. This research uses descriptive qualitative research methods, with data collection techniques through interviews, documentation study and observation. The results showed that the Darul Quran Islamic boarding school in Bandung was able to demonstrate its role in the national education system, through the Daqu method, and the Daili Activity which led the students to have attitudes, knowledge and skills to meet 21 st century competencies.
\end{abstract}

Keyword: The role of Islamic boarding schools, National education system, Islamic boarding school

\section{PENDAHULUAN}

Pesantren merupakan lembaga pendidikan yang sangat akrab di kalangan umat Islam Indonesia. Fokus pendidikan pesantren pada pendidikan keagamaan, dimana para santrinya belajar tentang hal-hal yang terkait dengan ajaran agama Islam. Sejarah mencatat bahwa lembaga pendidikan pesantren berawal dari adanya seorang kiai di suatu tempat, kemudian datang santri yang ingin belajar agama kepadanya, Setelah semakin 
hari semakin banyak santri yang datang, timbullah inisiatif untuk mendirikan pondok atau asrama di samping rumah kiai.

Pada saat itu kiai tidak merencanakan bagaimana membangun pondok santri, yang terpikir hanyalah bagaimana mengajarkan ilmu agama supaya dapat dipahami dan dimengerti oleh santri. Kiai belum memberikan perhatian terhadap tempat-tempat yang didiami oleh para santri, yang umumnya sangat kecil dan sederhana. Para santri menempati sebuah gedung atau rumah kecil yang mereka dirikan sendiri di sekitar rumah kiai. Semakin banyak jumlah santri, semakin bertambah pula gubuk yang didirikan.

Saat ini lembaga pendidikan pesantren dibangun atas inisiatif sebuah organisasi keagamaan atau lembaga yang menaungi berdirinya pesantren atau oleh Kyai itu sendiri. Pembangunan pondok pesantren dikelola dengan penuh perencanaan, dan ditata lebih baik demi kenyamanan para santri. Disamping Pengelolaan sarana pondok yang semakin tertata baik, dengan segala fasilitas pendukungnya, pendidikan keagamaannyapun sudah terstruktur serta dilengkapi dengan pendidikan ilmu-ilmu lainnya di luar pendidikan keagamaan.

Animo dan kepercayaan masyarakat terhadap lembaga pendidikan pesantren, semakin tinggi, terutama pada pesantren yang melakukan kolaborasi kurikulum antara kurikulum dari kementrian agama dengan kurikulum dari kementrian pendidikan dan kebudayaan. Beberapa pesantren memiliki keunggulan-keunggulan tersendiri, yang menjadi kekhasan ketika pesantren itu dibangun, misalnya keunggulan di bidang bahasa, bidang pemanfaatn teknologi, keunggulan Hafiz, dan lainnya.

Sistem pesantren telah menjadi institusi yang lahir dari masyarakat dan diakui keberadaannya oleh masyarakat sebagai institusi pendidikan Islam. Para santri menerima pembelajaran agama maupun akhlak melalui pengajian dan pembiasaan yang mereka lakukan setiap hari di pondok pesantren serta pendidikan formal berupa madrasah yang sepenuhnya di bawah komando dan kedaulatan seorang atau beberapa orang kiai (majelis masyaikh). Kepemimpinan kiai yang berwatak kharismatik dan independen dalam semua keputusannya menjadikan pondok pesantren tidak terlalu ketat terhadap aturan pendidikan yang dikeluarkan oleh kementerian pendidikan, namun dalam pendidikan formal, para kiai tetap patuh pada aturan pemerintah. Pondok pesantren berkembang pesat di tanah air jauh sebelum Negara Indonesia merdeka bahkan sebelum nama Indonesia muncul, sehingga bisa dikatakan pendidikan pesantren merupakan pendidikan yang telah berusia tua. ${ }^{1}$

Dalam memberikan pengajaran, para kiai mengutamakan akhlak yang baik. Karena tujuan lain dari pengajaran di pondok pesantren adalah membentuk akhlak yang mulia dan mendidik jiwa agar mengetahui tuhannya. Akhlak mulia ini dapat dilihat dari keseharian santri yang mencerminkan sikap takwa, taat, jujur, amanah, dan lain sebagainya. $^{2}$

Zaman sekarang persaingan di dalam lapangan kerja semakin sulit dan selektif karena lowongan kerja tidak sebanding dengan calon pekerja. Akibat dari hal tersebut

\footnotetext{
${ }^{1}$ Tamlihah Tamlihah, Abd. Mukhid, and Hilmi Qosim Mubah, "Implementasi Manajemen Kurikulum Pesantren Dalam Membentuk Karakter Mandiri Santri Di Pondok Pesantren Nurus Sibyan Ambat Tlanakan Pamekasan," Re-JIEM (Research Journal of Islamic Education Management) 3, no. 1 (2020): 98, https://doi.org/10.19105/re-jiem.v3i1.2957.

${ }^{2}$ Hilmi Qosim Mubah, Manajemen Pesantren Dan Pendidikan Luar Sekolah (Pamekasan: iainmadura press, 2019), 65 .
} 
adalah lulusan yang berkualitas menjadi prioritas utama untuk diterima bekerja daripada lulusan yang tidak berkualitas. Begitu juga dengan pelayanan institusi pendidikan yang berkualitas semakin hari semakin dibutuhkan dan dicari oleh masyarakat. Lembaga pendidikan harus mengusahakan dengan segala cara dalam rangka menaikkan kompetensi output/lulusan serta hasil-hasil akademik yang lainnya, itu dilakukan dalam rangka mempersiapkan diri menghadapi transformasi zaman dan teknologi serta sendisendi kehidupan yang semakin kencang dan untuk menghadapi tantangan yang kian lama menjadi besar, contoh konkrit upaya tersebut adalah peningkatan mutu pendidikan. ${ }^{3}$ Dalam kaitannya dengan hal tersebut, penguatan alumni pondok pesantren dalam peningkatan dan pengembangan kualitas serta kreatifitas santri alumni menjadi hal utama yang tidak bias diabaikan oelh pondok pesantren.

Alumni pesantren saat ini tidak diragukan lagi kualifikasinya, banyak diantara mereka yang menunjukkan pengabdiannya pada bangsa dan negara, mereka sangat memegang teguh NKRI dan kemajuan bangsa Indonesia. KH Abdurahman Wahid (Gusdur), H. Abdul Malik Karim Amrullah (Buya Hamka), Nurcholish Madjid (Cak Nur), merupakan alumni pesantren yang menjadi tokoh bangsa dan negarawan yang dikenal oleh semua lini masyarakat, bahkan lintas agama, serta tidak diragukan lagi akan kecintaannya terhadap bangsa dan NKRI.

Banyaknya alumni pesantren yang menjadi tokoh bangsa dan berkiprah di berabagai sektor, membuktikan bahwa pesantren memiliki peranan besar terhadap kemajuan bangsa dan negara, ini menunjukkan bahwa proses pendidikan di pesantren sesuai dengan arah kebijakan atau undang-undang sistem pendidikan Nasional. Bagaimana Pondok pesantren menerapkan arah kebijakan sistem pendidikan nasional dalam proses pembelajarannya, akan digambarkan dalam makalah ini. Adapun pondok pesantren yang menjadi sampel pembahasan tentang peranan pondok pesantren dalam menerapkan sistem pendidikan nasional, adalah pondok pesantren Darul Quran Kota Bandung.

\section{METODE PENELITIAN}

Metode yang digunakan dalam mengkaji peranan pesantren dalam sistem pendidikan nasional di pesantren Darul Quran Kota Bandung adalah metode penelitian kualitatif deskriftif.

Alasan pemilihan pendekatan dan jenis ini karena data yang dikumpulkan berupa kalimat-kalimat penyataan, foto-foto serta dokumen pendukung bukan merupakan penghitungan angka-angka. Laporan penelitian ini berisi kutipan-kutipan data untuk memberi deskripsi untuk penyajian hasil penelitian ini. Data penelitian ini bersumber dari teks hasil wawancara, catatan hasil observasi lapangan, foto, serta memo. ${ }^{4}$

\footnotetext{
${ }^{3}$ Muchlis Solichin, Moh. Hafidz, and Hilmi Qosim Mubah, "Kualitas Program Persiapan Guru Tugas Di Pondok Pesantren Mambaul Ulum Bata-Bata Panaan Palengaan Pamekasan," Re-JIEM (Research Journal of Islamic Education Management) 2, no. 2 (2019): 308, https://doi.org/10.19105/rejiem.v2i2.2870.

${ }^{4}$ Rofiatun Rofiatun and Mohammad Thoha, "Manajemen Pembinaan Kedisiplinan Santri Dalam Mengikuti Kegiatan Keagamaan Di Pondok Pesantren Nurus Shibyan Ambat Tlanakan Pamekasan," ReJIEM (Research Journal of Islamic Education Management) 2, no. 2 (2019): 283, https://doi.org/10.19105/re-jiem.v2i2.2937.
} 
Penelitian ini memakai pendekatan kualitatif karena bertujuan untuk menyajikan dunia sosial, dan perspektifnya di dalam dunia, dari segi konsep, perilaku, persepsi dan persoalan tentang manusia yang diteliti. Selain itu dengan pendekatan ini diharapkan peneliti akan lebih dekat pada subjek penelitian yang akan diteliti serta lebih peka dan akan lebih berinteraksi dalam penyesuaian diri. ${ }^{5}$

Data yang dikumpulkan diperoleh melalui teknik wawancara langsung dengan Kepala sekolah Darul Quran, dan para ustad / pimpinan pondok, sebagai data primer, sedangkan data sekundernya diperoleh melalui teknik pengamatan (observasi), studi dokumentasi dan kajian literasi dari berbagai sumber.

\section{HASIL DAN PEMBAHASAN}

Pesantren merupakan lembaga pendidikan keagamaan Islam berbasis masyarakat baik sebagai satuan pendidikan dan / atau sebagai wadah penyelenggaraan pendidikan. Lembaga pendidikan keagamaan dapat dinamakan pesantren jika memiliki (a) Kyai, ustad, atau sebutan lain yang sejenis, (b) santri, (c) pondok atau asrama, dan (d) masjid atau musala. Lembaga pendidikan Al-Quran adalah lembaga atau kelompok masyarakkat yang menyelenggarakan pendidikan keagaan Islam yang bertujuan untuk memberikan pengajaran bacaan, hafalan, dan pemahaman Al Quran. ${ }^{6}$

Sesuai peraturan mentri agama tersebut di atas, Pesantren Darul Quran Bandung sebagai sebuah lembaga pendidikan pesantren sudah memenuhi syarat penyelenggara pendidikan keagamaan Islam dalam bentuk pesantren. Pesantren Darul Quran Kota Bandung memiliki Kyai, yang dipimpin oleh Kyai Khairurozi, M.Sy Al-Hafizh, memiliki santri, ada pondok (tempat tidur santri) putra dan putri, dan ada Masjid, tempat ibadah para santri.

Sejarah berdirinya Darul Quran, tidak lepas dari sosok ustad Yusuf Mansyur, yang memiliki perhatian tinggi terhadap pembelajaran pengahapalan Al Quran. Awalnya Pesantren Darul Quran merupakan sebuah mimpi Program Pembibitan Penghafal Alquran (PPPA) seribu pondok, dengan konsep santri menyebar di beberapa masjid untuk belajar menghapal Quran, didampingi seorang guru hafidz yang disewakan rumah di sekitar masjid. Mimpi seribu pondok belum terwujud, karena PPPA Darul Quran, menemukan sebuah tempat yang cocok dijadikan pondok, tepatnya di kelurahan Pondok Pucung Kecamatan Karang Tengah, Ciledug, Tangerang, Banten, maka bersama jamaah Wisata Hati, ustad Yusuf Mansur mendirikan Pesantren Tahfizh Qur'an di Bulak Santri Tangerang.

Tahun 2005, KH. Yusuf Mansur, melalui Yayasan Daarul Qur'an Indonesia yang dibentuknya, meminta izin ke Departemen Pendidikan dan Kebudayaan untuk mendirikan sekolah formal. Tujuannya agar para santri dapat belajar di dalam pesantren, tidak perlu ke luar pondok seperti yang selama ini sudah berjalan, berdirilah SMP Islam Darul Quran, selanjutnya berkembang ke tingkat SMA.

Pada tahun 2008, KH. Yusuf Mansur mengembangkan pesantren menjadi pesantren bertaraf Internasional, maka berdirilah Sekolah Daarul Qur'an Internasional (SDQI) yang bertempat di Jl. Thamrin Ketapang, kelurahan Ketapang Kecamatan Cipondoh, Kota Tangerang, Provinsi Banten. Pesantren yang mencakup jenjang SMP-SMA

\footnotetext{
${ }^{5}$ Rofiatun and Thoha, 283.

${ }^{6}$ PMA Nomor 3 tahun 2012, tentang Pendidikan Keagamaan islam
} 
menggunakan Cambridge Curriculum untuk pelajaran Math, Science, English dan IT. Tingkat Primary (SD) menggunakan IB Curriculum dan DIKNAS, serta tingkat TK menggunakan kurikulum PAUD.

Sekolah Daarul Qur'an Kota Bandung, semula berawal di Ketapang Tangerang, ketika sekolah sedang melaksanakan pembangunan bangunan infrastruktur, maka untuk sementara dipindahkan ke daerah Bandung tepatnya di Graha 11 Gegerkalong Kecamatan Sukasari, bangunan milik KH Abdullah Gymnastiar. Setelah berjalannya waktu ternyata sekolah Daarul Qur'an tidak kembali ke Ketapang Tangerang, tetapi menjadi pelebaran sayap Daarul Qur'an di Daerah Bandung. Melalui wakaf dari Kyai Yusuf Mansur dan disokong Jamaahnya, maka sekolah darul Quran telah berdiri di Kota Bandung, tepatnya di Jalan Nagrog nomor 85 kampung Ciwaru Kelurahan Pasanggrahan Kecamatan Ujung Berung Kota Bandung Provinsi Jawa Barat.

Sampai tahun 2009 Daarul Qur'an masih menggunakan kurikulum Cambridge, tetapi secara perlahan dan pasti, kurikulum cendrung mengarah ke kurikulum Nasional. Maka pada tahun 2010 kurikulum utama SMA Darul Quran menggunakan Kurikulum Tingkat Satuan Pendidikan (KTSP) dan kurikulum Cambridge sebagai pilihan. Disamping itu santri di pondok pesantren Darul Quran masih mempelajari pembelajaran keagamaan sebagai karakteristik sebuah pondok pesantren, hal ini sesuai dengan PMA No. 3 tahun 2020 pasal 41, bahwa pesantren dapat menyelenggarakan pendidikan umum dengan kekhasan Islam.

Tujuan pendidikan di pesantren tidak semata-mata untuk memperkaya pikiran santri dengan penjelasan-penjelasan, tetapi untuk meningkatkan moral, melatih dan mempertinggi semangat, menghargai nilai-nilai spiritual dan kemanusiaan, mengajarkan sikap dan tingkah laku yang jujur dan bermoral serta menyiapkan para santri belajar mengenai etika agama di atas etika-etika yang lain. Lebih khusus lagi, tujuan pendidikan pesantren bukan untuk mengejar kepentingan kekuasaan, uang dan keagungan duniawi, tetapi menanamkan para santri bahwa belajar adalah semata-mata kewajiban dan pengabdian kepada Tuhan. Pesantren sebagai tempat untuk melatih santri agar dapat berdiri sendirin dan membina diri agar tidak menggantungkan sesuatu kepada orang lain kecuali kepada Tuhan. ${ }^{7}$

Jika dilihat dari uraian tersebut di atas, maka tujuan pesantren selaras dengan fungsi dan tujuan pendidikan Nasional yaitu berfungsi untuk mengembangkan kemampuan dan membentuk watak serta peradaban bangsa yang bermartabat dalam rangka mencerdaskan kehidupan bangsa, bertujuan untuk berkembangnya potensi peserta didik agar menjadi manusia yang beriman dan bertakwa kepada Tuhan Yang Maha Esa, berakhlak mulia, sehat, berilmu, cakap, kreatif, mandiri, dan menjadi warga negara yang demokratis serta bertanggung jawab. ${ }^{8}$

Potensi potensi yang akan dikembangkan melalui proses pendidikan, seperti yang telah diuraikan dalam tujuan pendidikan tersebut, merupakan potensi atau kemampuan peserta didik/para santri yang sebetulnya sudah ada atau telah dimiliki dan melekat dalam jiwa peserta didik. Potensi ketuhanan misalnya, telah dijelaskan melalui Firman-Nya

\footnotetext{
${ }^{7}$ Zamakhsyari Dhofier, Tradisi Pesantren: Studi Pandangan Hidup Kyai Dan Visinya Mengenai Masa Depan Indonesia (Jakarta: LP3ES, 2011), 49.

${ }^{8}$ UU Sistem Pendidikan Nasional No 20 tahun 2003.
} 
bahwa Allah tidak menciptakan jin dan manusia kecuali untuk menyembah-Ku. (QS. Adz Dzariyat: 56).

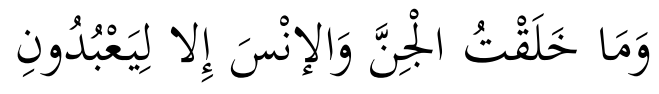

Potensi akhlak mulia dan potensi berpikir yang dijadikan tujuan pendidikan Nasional, termasuk pula pada potensi-potensi yang sudah melekat dan ada dalam diri setiap individu. Pada dasarnya Allah telah memberikan bekal kepada setiap individu untuk mengembangkan potensi berakhlak mulya dan potensi berpikirnya. Melalui alat qalb dan akal, Allah membekali individu untuk memilih kefitrahan dalam segala aspek kehidupan. Qalb dan akal membimbing manusia untuk melaksanakan amanah Allah sebagai khalifah di muka bumi. Qalbu dan akal, merupakan anugrah Allah yang diberikan kepada manusia, sebagai pembeda dengan mahluk Allah lainnya.

Qalb merupakan suatu anugerah Allah swt. yang diberikan kepada manusia yang mempunyai kedudukan dan fungsi yang sangat penting dan utama, sebab qalb berfungsi sebagai penggerak dan pengontrol anggota tubuh lainnya. Peranan qalb menjadi sangat penting sekali melihat potensi- potensi yang ada di dalamnya. Termasuk potensi untuk selalu mengarahkan manusia ke arah kebaikan. Dalam pandangan al- Ghazali bahwa manusia dengan nalar qalb-nya pada dasarnya dapat membenarkan wahyu Allah swt. meski daya rasionalnya menolak. Dengan demikian, adanya potensi qalb sangat dimungkinkan memiliki fungsi menuntun seseorang ke arah kesalihan tingkah laku lahiriah sesuai yang digariskan wahyu yang bersifat supra rasional. ${ }^{9}$

Perintah Allah agar manusia mengembangkan potensi berpikirnya melalui akal, banyak difirmankan dalam alquran, salah satunya firman Allah yang memerintahkan manusia untuk menggunakan akalnya tercantum dalam quran surat albaqarah ayat 165, yang artinya "Sesungguhnya dalam penciptaan langit dan bumi, pergantian malam dan siang, bahtera-bahtera yang berlayar di laut membawa apa yang berguna bagi manusia dan apa yang Allah turunkan dari langit berupa air, lalu dengan air itu Dia hidupkan (suburkan) bumi sesudah mati (kering)-Nya dan Dia sebarkan di bumi itu segala jenis hewan, dan pengisaran angin dan awan yang dikendalikan antara langit dan bumi; (pada semua itu) sungguh terdapat tanda-tanda bagi kaum yang berakal."

Akal adalah salah satu fungsi jiwa yang terjadi ketika ruh masuk ke dalam badan, dan banyak berkaitan dengan fungsi memikirkan, merenungkan dan mempertimbangkan. Professor Izutzu dalam God and Man in the Quran mengatakan bahwa di zaman jahiliyah kosakata akal dipakai untuk arti kecerdasan praktis (practicial intelligence), dan dalam psikolog modern disebut kecakapan memecahkan masalah (problem-solving capacity). Menurut pendapatnya "bahwa orang yang berakal adalah orang yang mempunyai kecakapan untuk menyelesaikan masalah, setiap kali ia dihadapkan dengan problem, dan selanjutnya dapat melepaskan diri dari bahaya yang ia hadapi". ${ }^{10}$

Jika potensi-potensi itu sudah melekat dalam diri setiap individu dan atau peserta didik/santri, maka secara logika, sebuah lembaga pendidikan pesantren akan lebih mudah mendorong untuk mengembangkan potensi-potensi dimaksud. Berkembangnaya potensi

\footnotetext{
9 Mansyur, “Al-Qolbu Dalam Perspektif Al-Qur'an,” Tafsere 5, no. 1 (2017): 46, http://journal.uinalauddin.ac.id/index.php/tafsere/article/view/7318/6002.

${ }^{10}$ Abuddin Nata, Psikologi Pendidikan Islam (Depok: Rajawali Pers, 2018), 162.
} 
perlu didukung oleh lingkungan atau perlu dikondisikan melalui stimulus-stimulus dari lingkungan peserta didik. Bandura dengan teori Behaviristiknya menyatakan bahwa pembentukan prilaku individu dipengaruhi oleh lingkungan, dan potensi yang dimiliki individu juga akan mempengaruhi lingkungan, Bandura menyebutnya sebagai determinisme resiprokal, yaitu dunia dan prilaku seseorang saling mempengaruhi. Lebih jauh Bandura menyatakan bahwa kepribadian sebagai hasil interaksi dari tiga hal; yaitu lingkungan, prilaku dan proses psikologi seseorang. ${ }^{11}$

Sebuah hadits Bukhari-Muslim meriwayatkan bahwa Rasulullah Saw bersabda, "Setiap manusia dilahirkan di atas fitrah. Kedua orang tuanya yang menjadikannya Yahudi, Nasrani, atau Majusi.

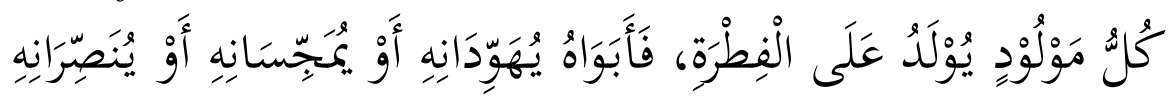

Fitrah merupakan sebuah pengakuan atau komitmen ruh ketika berdialog dengan Allah, peristiwa ini digambarkan dalam QS Al A'raf: 172, yang artinya; Dan (ingatlah), ketika Tuhanmu mengeluarkan keturunan anak-anak Adam dari sulbi mereka dan Allah mengambil kesaksian terhadap jiwa mereka (seraya berfirman): "Bukankah Aku ini Tuhanmu?" Mereka menjawab: "Betul (Engkau Tuhan kami), kami menjadi saksi". (Kami lakukan yang demikian itu) agar di hari kiamat kamu tidak mengatakan: "Sesungguhnya kami (bani Adam) adalah orang-orang yang lengah terhadap ini (keesaan Tuhan)",

Hadits tersebut menekankan, bahwa jikapun seorang individu itu telah memiliki fitrah ketuhanan, fitrah qalbu dan akal, tetapi orangtualah yang menguatkan atau bahkan mengubah fitrah tersebut. Orangtua bisa dimaknai sebagai orang yang melahirkan seorang anak, bisa juga dimaknai sebagai lingkungan di mana seorang individu melakukan aktifitasnya, misalnya lingkungan lembaga pendidikan atau lembaga pesantren.

Pesantren Darul Quran Bandung, sebagai sebuah lembaga pendidikan, lingkungan para santri menetap, tumbuh dan berkembang, telah menetapkan visi dan misinya sesuai dengan tujuan pendidikan nasional, yaitu akan melahirkan generasi Qur'ani yang berakhlakul karimah dan berdaya saing global. Pencapaian tujuan pendidikan nasional di lembaga pesantren Darul Quran tercermin dari para santrinya sebagai pembelajar yang unggul, mampu mengikuti perkembangan teknologi, serta mahir berbahasa sebagai alat untuk menguasai globalisasi, sehingga mampu bersaing dengan akhlak Quran.

Kurikulum 2013 sebagai kurikulum yang dilaksanakan di pesantren Darul Quran Bandung, telah mempersiapkan santrinya untuk memiliki kecakapan abad 21, sebagai karakteristik kurikulum 2013. Kecakapan abad 21 merupakan pembelajaran yang mengintegrasikan kemampuan literasi, kecakapan pengetahuan, keterampilan dan sikap, serta penguasaan terhadap teknologi. Literasi menjadi bagian terpenting dalam sebuah proses pendidikan, peserta didik yang dapat melaksanakan kegiatan literasi dengan maksimal tentunya akan mendapatkan pengalaman belajar lebih dibanding dengan peserta didik lainnya. Kecakapan tersebut dapat dikembangkan melalui berbagai model pembelajaran berbasis aktivitas yang sesuai dengan karakteristik kompetensi dan materi pembelajaran. Keterampilan berpikir lebih tinggi (Higher Order Thinking Skills

${ }^{11}$ George Boeree, Personality Theories (Yogyakarta: Prismasophi, 2007), 264-65. 
(HOTS)), merupakan kecakapan yang juga dibutuhkan dalam memiliki kecakapan abad $21^{12}$

Literasi di Darul Quran, telah berjalan dan berkembang seiring dengan kegiatan harian (daily activity). Setiap hari senin dan hari selasa, para santri melakukan kegiatan membaca dan meresume sebuah buku, serta membaca kitab, dipandu pembimbing santri. Pada hari rabu, santri melakukan sorogan, yaitu metode pembelajaran dimana santri menirukan bacaan Kyai, kemudian diulang oleh santri tersebut satu persatu di ahadapan kyainya untuk dikoreksi bacaan tersebut. ${ }^{13}$ Semua pesantren memberikan system sorogan, yaitu sistem yang paling sulit dari keseluruhan sistem pendidikan pesantren, karena menuntut kesabaran, kerajinan, ketaatan dan disiplin pribadi guru pembimbing dan murid. ${ }^{14}$

Memasuki abdi 21, dunia memasuki abad globalisasi, abad kemajuan teknologi industri digital yang melanda seluruh penjuru dunia, gerakan revolusi industri 4.0, yang ditandai dengan perubahan yang cepat, mengejutkan, memindahkan. ${ }^{15}$ Lebih lanjut Kasali menjelaskan bahwa ada enam hal penting yang perlu dicermati dalam menyikapi perubahan;

Pertama, teknologi telah mengubah dunia, serta membuat segala produk menjadi jasa yang serba digital, dan membentuk marketplace baru, platform baru. Kedua, adanya generasi baru pendukung utama gerakan ini, yang dikenal dengan generasi millenial. Ketiga, kecepatan yang luar biasa dari microprocessor dengan kapasitas ganda setiap 24 bulan, menyebabkan teknologi bergerak lebih cepat dan menuntut manusia berpikir, bertindak dan merespon lebih cepat tanpa keterikatan pada waktu, serta tempat menjadi sebuah disruptive mindset. Keempat, sejalan dengan gejala distrupted society, muncullah disruptive leader, yang dengan keasadaran penuh menciptakan perubahan dan kemajuan melalui cara-cara baru, sehingga jelas menuntut mindnset baru; disruptive mindset, para pemimpin memanfaatkan internet sebagai media untuk membesarkan dirinya, dengan cara self-distruption, para aparat melakukan pelayanan menjadi 24 jam dengan memanfaatkan smartphone, mereka lebih proaktif dan hidup dalam corporate mindset. Kelima, cara-cara mengeksplorasi kemenangan mengalami perubahan, model-model bisnis baru yang sangat disruptive mengakibatkan barang dan jasa lebih terjangkau, lebih mudah terakses, lebih sederhana dan merakyat, ada sharing economy, on demand economy dan segala hal yang lebih real time. Keenam, teknologi telah memasuki gelombang internet of things, dunia memasuki gelombang smart device, mendorong semua hidup dalam karya-karya yang kolaboratif, ada smart home, smart city dan smart shopping, merupakan realitas baru yang harus dihadapi yang menciptakan peluang sekaligus ancaman.

Ancaman yang digambarkan Kasali, menjadi tantangan buat lembaga pendidikan pesantren. Bagaimana mempersiapkan para santri agar tidak terdidistrupsi dengan

\footnotetext{
${ }^{12}$ Dirjen Pembinaan SMA, Panduan Implementasi Kecakapan Abad 21 Kurikulum 2013 Di SMA (Jakarta: Dirjen Pembinaan SMA, 2017).

${ }^{13}$ Su'udiyah Hasanah, "Sorogan; Metode Warisan Pesantren Yang Berumur Panjang," Ringtimes Banyuwangi, 2020, https://ringtimesbanyuwangi.pikiran-rakyat.com/pendidikan/pr-17616097/soroganmetode-warisan-pesantren-yang-berumur-panjang.

${ }^{14}$ Dhofier, Tradisi Pesantren: Studi Pandangan Hidup Kyai Dan Visinya Mengenai Masa Depan Indonesia, 54.

${ }^{15}$ Rhenald Kasali, Discruption (Jakarta: Kompas Gramedia, 2018), xx-xxi.
} 
kemajuan teknologi industri yang mengalami perubahan cepat, mengejutkan dan memindahkan. Mau tidak mau atau suka tidak suka, pesantren harus mempersiapkan para santrinya untuk menyongsong abad 21, dengan kompetensi kecakapan abad 21.

Darul Quran telah mempersiapkan santrinya untuk memiliki keterampilan berpikir tingkat tinggi (HOTS), dengan mendorong santri untuk mengoptimalkan fitrahnya dalam menghadapi tantangan dan tuntutan abad 21. Dengan Qalb dan akal yang terlatih dan difasilitasi oleh pondok, mengantarkan santri Darul Quran terbiasa dengan perubahanperubahan yang discruption. Kekhasan pembelajaran pesantren Darul Quran dengan Daqumethod, mengantarkan santri siap dengan perubahan-perubahan yang begitu cepat dan mengejutkan.

Berpikir kritis, berpikir kreatif dan inovatif, komunikatif serta kolaboratif, merupakan kompetensi kecakapan abad 21 yang perlu dikuasai para santri. Empat kompetensi ini pada dasarnya sudah terkondisikan di pesantren Darul Quran. Jadwal aktifitas harian (daily activity), merupakan proses latihan para santri agar memiliki kompetensi kecakapan abad 21. Para santri sudah mulai melakukan aktifitasnya pada pukul 03.45, diakhiri sampai menjelang tidur pukul 21.30., artinya dalam satu hari para santri menghabiskan waktu sekitar 17 jam 45 menit untukberaktifitas, sedangkan waktu istirahat yang disediakan untuk para santri, hanya 6 jam 15 menit. Waktu yang padat dengan segudang aktifitas, mendorong santri untuk lebih bersikap kritis, kreatif dan inovatif dalam menyikapi kegiatan-kegiatan tersebut menjadi sebuah aktifitas yang bermanfaat dan menyenangkan. Melalui pengalaman nyata, dengan masalah-masalah yang menyertai aktifitasnya, para santri belajar menemukan solusi, mengembangkannya menjadi sebuah solutif yang produktif.

Daily activity, sebuah kegiatan yang melatih para santri menghadapi tantangan harian nyata yang biasa dan terbiasa dihadapi dan dilakukan para santri Darul Quran. Semua aktifitas dilakukan dengan penuh tanggung jawab dan kemandirian sangat tinggi, tetapi tetap membangun kebersamaan (kolaboratif) serta memelihara komunikasi yang cerdas diantara para santri. Kecerdasan inilah yang dibutuhakan para santri dalam menghadapi tantangan abad 21, kecerdasan emosi dan kecerdasan sosial.

Kecerdasan emosional adalah kecerdasan yang mencakup pengendalian diri, semangat dan ketekunan serta kemampuan untuk memotivasi diri sendiri. Kecerdasan ini memberi peluang yang lebih baik dalam memanfaatkan potensi intelektualnya, individu yang dikuasai dorongan hati yang kurang memiliki kendali diri, menderita kekurangmamouan pengendalian moal. Kemampuan mengendalikan dorongan hati merupakan basis kemauan (will) dan watak (character). ${ }^{16}$

Kecerdasan Sosial dirumuskan oleh Psikolog Edward Thorndike sebagai kemampuan memahami dan mengelola orang lain, dan merupakan keterampilan yang dibutuhkan setiap orang untuk hidup dengan baik. Lebih luas lagi pengertian kecerdasan sosial merupakan kemampuan-kemampuan yang memperkaya relasi pribadi, seperti empati dan kepedulian, atau kemampuan bertindak dengan bijak dalam hubungan antar manusia. ${ }^{17}$

Pada jadwal daily activity kegiatan santri Darul Quran, hari Kamis dan Jumat diisi dengan kegiatan yang mengembangkan keterampilan santri dalam menguasai kompetensi

\footnotetext{
${ }^{16}$ Daniel Goleman, Emotional Intelligence (Jakarta: Gramedia, 2015), xiii.

${ }^{17}$ Daniel Goleman, Social Intelligence (Jakarta: Gramedia, 2015), xxi.
} 
kompetensi kolaborasi dan komunikasi. Setiap santri bekerja sama dalam satu kelompok untuk mendiskusikan suatu permasalahan yang berkaitan dengan fiqih dan mencari solusi. Tentunya ini membutuhkan keterampilan santri untuk mengkolaborasikan antara kecakapan berpikir kritis terhadap permasalahan, kreatif mencari solusi, serta inovatif dalam mengembangkan solusi, dan hal ini akan terwujud, jika santri memiliki keterampilan dalam berkolaborasi dan komunikasi.

Unggulan pesanten Darul Quran adalah menyiapkan santrinya menjadi Hafidz dan Hafidzah $30 \mathrm{Juz}$ selama mondok di pesantren. Kegiatan pendukung agar santri menjadi Hafidz dan Hafidzah 30 Juz, melalui daily activity. Kegiatan diawali pada pukul 04.15. santri terjadwal harus melakukan tilawah/murajaah, yaitu kegiatan untuk menjaga hapalan Quran dengan terus-menerus mengulangnya sehingga santri kuat (mutqin) dalam bacaan, hafalan, pemahaman, dan pengamalannya. Kegiaan ini di ulang dengan kegiatan tahfidz pagi, tahfidz sore dan tahfidz malam menjelang tidur. Kegiatan ini melatih santri memiliki jiwa yang tangguh, kuat dan siap menghadapi tantangan.

Daily activity Darul Quran yang membutuhkan kesabaran, keuletan, keikhlasan serta kepatuhan sebagi hamba yang bertaqwa, adalah kegiatan shalat wajib berjamaah lima waktu, qiyamul lail dan shalat dhuha, serta tadarus Al-Qur'an bada salat dhuha dan salat asar, dan pembacaan Hadits. Pada usia remaja, kegiatan rutin keagamaan perlu dilakukan dengan intervensi melalui pengkondisian. Supaya individu atau manusia berkembang menjadi seorang pribadi yang beragama (beriman dan bertaqwa) dan mengembangkan budaya "rahmatan lil alamin" perlu diberikan intervensi. ${ }^{18}$

Daily activity Darul Quran yang membutuhkan kemandirian, disiplin, tenggang rasa, terlihat pada aktifitas merapihkan kamar (satu kamar dihuni oleh 4 orang santri), dan pemggunaan kamar mandi (satu kamar satu kamar mandi), harus bergantian dalam menggunakannya. Jika santri abai terhadap tugas mandirinya, tidak disiplin dan tidak ada tenggang rasa, maka bisa menimbulkan komunikasi terhambat diantara santri satu kamar, dan terjadi konflik. Keterampilan sosial ini perlu dilatih, karena secara psikologis perkembangan psikososial usia remaja cendrung egosentrisme, yakni remaja cendrung menerima dunia (dan dirinya sendiri) dari perspektif mereka sendiri, dimana remaja lebih memikirkan tentang dirinya sendiri.... ${ }^{19}$

Keunggulan lain dari pesantren Darul Quran adalah banyaknya pilihan kegiatan ekstrakurikuler untuk mengembangkan minat dan potensi para santri. Adapun kegiatan ekstrakurikulernya adalah; hadroh, kaligrafi, panahan, futsal, basket, badminton, renang, pramuka, pencak silat, paskibra, tari saman, angklung dan perkusi. Aktifitas ekstrakurikuler, sebagai sebuah pengkondisian untuk mengembangkan potensi-potensi para santri dalam mengoptimalkan kecerdasan. Garder seorang Psikolog, mengungkapkan bahwa kecerdasan seseorang itu tidak hanya diukur dari skor nilai IQ, menurutnya itu terlalu sempit untuk mendefinisikan sebuah kecerdasan. Dalam bukunya Frames of Mind, dengan teori Multiple Intellegence (MI), Garder mengemukakan, bahwa setidaknya ada tujuh sampai delapan kecerdasan seorang individu, yaitu kecerdasan Lingusitik, Logic-matenatis, spasial, kinestetik, musical, interpersonal, intrapersonal dan naturalistik. $^{20}$

\footnotetext{
${ }^{18}$ Syamsu Yusuf, Psikologi Perkembangan Anak Dan Remaja (Bandung: Remaja Rosdakarya, 2006), 143.

${ }^{19}$ Desmita, Psikologi Perkembangan (Bandung: Remaja Rosdakarya, 2006), 205.

${ }^{20}$ Thomas Amstrong, Kecerdasan Multiple Edisi Ketiga (Jakarta: Indeks, 2013), 5-7.
} 
Proses pendidikan di Pesantren Darul Quran dengan Daqu Method, melalui strategi Daily activity Darul Quran, dan unggulan Hafidz dan Hafidzah 30 juz, para lulusan santrinya mampu bersaing dalam melanjutkan ke perguruan tinggi. Hampir $90 \%$ siswa melanjutkan ke perguruan tinggi negri ataupun perguruan tinggi swasta, serta perguruan tinggi di luar negeri. Kondisi ini sesuai dengan tujuan dari sistem pendidikan di tingkat SMA, bahwa lulusan sekolah menenagh atas lulusannya mampu terserap di perguruan tinggi.

\section{KESIMPULAN}

Proses pendidikan di pesantren Darul Quran, merupakan proses pendidikan yang mengantarkan santrinya memiliki kecakapan dan keterampilan abad 21, sesuai dengan tuntutan kompetensi kurikulum 2013 dan selaras dengan tujuan pendidikan nasional. Pembentukan watak atau karakter bangsa yang bermartabat, untuk mencerdaskan kehidupan bangsa dibutuhkan pembiasaan dan pengkondisian melalui proses pendidikan, sehingga akan terbentuk jiwa yang sehat, yaitu adanya keselarasan antara qalbu dan akal.

Daily Activity Darul Quran, memotivasi para santri untuk melatih dirinya secara mandiri sehingga memiliki kecerdasan emosi dan kecerdasan sosial serta mampu mengembangkan kecerdasan multiple. Melalui kecakapan berpikir kritis, kreatif dan inovatif dan keterampilan kolaboratif dan komunikatif, serta pengemabangan literasi, mengantarkan pesantren Darul Quran sebagai bagian dari sebuah sistem pendidikan nasional, dengan pencapaian alumni santri cerdas, berkarakter dan ber-akhlakul karimah.

\section{DAFTAR PUSTAKA}

Amstrong, Thomas. Kecerdasan Multiple Edisi Ketiga. Jakarta: Indeks, 2013.

Boeree, George. Personality Theories. Yogyakarta: Prismasophi, 2007.

Desmita. Psikologi Perkembangan. Bandung: Remaja Rosdakarya, 2006.

Dhofier, Zamakhsyari. Tradisi Pesantren: Studi Pandangan Hidup Kyai Dan Visinya Mengenai Masa Depan Indonesia. Jakarta: LP3ES, 2011.

Goleman, Daniel. Emotional Intelligence. Jakarta: Gramedia, 2015.

Social Intelligence. Jakarta: Gramedia, 2015.

Hasanah, Su'udiyah. "Sorogan; Metode Warisan Pesantren Yang Berumur Panjang."

Ringtimes Banyuwangi, 2020. https://ringtimesbanyuwangi.pikiranrakyat.com/pendidikan/pr-17616097/sorogan-metode-warisan-pesantren-yangberumur-panjang.

Kasali, Rhenald. Discruption. Jakarta: Kompas Gramedia, 2018.

Mansyur. “Al-Qolbu Dalam Perspektif Al-Qur'an.” Tafsere 5, no. 1 (2017): 45-66. http://journal.uin-alauddin.ac.id/index.php/tafsere/article/view/7318/6002.

Mubah, Hilmi Qosim. Manajemen Pesantren Dan Pendidikan Luar Sekolah. Pamekasan: iainmadura press, 2019.

Nata, Abuddin. Psikologi Pendidikan Islam. Depok: Rajawali Pers, 2018.

Rofiatun, Rofiatun, and Mohammad Thoha. "Manajemen Pembinaan Kedisiplinan Santri Dalam Mengikuti Kegiatan Keagamaan Di Pondok Pesantren Nurus Shibyan Ambat Tlanakan Pamekasan." Re-JIEM (Research Journal of Islamic Education Management) 2, no. 2 (2019): 278. https://doi.org/10.19105/re-jiem.v2i2.2937.

SMA, Dirjen Pembinaan. Panduan Implementasi Kecakapan Abad 21 Kurikulum 2013 Di SMA. Jakarta: Dirjen Pembinaan SMA, 2017. 
Solichin, Muchlis, Moh. Hafidz, and Hilmi Qosim Mubah. "Kualitas Program Persiapan Guru Tugas Di Pondok Pesantren Mambaul Ulum Bata-Bata Panaan Palengaan Pamekasan." Re-JIEM (Research Journal of Islamic Education Management) 2, no. 2 (2019): 305. https://doi.org/10.19105/re-jiem.v2i2.2870.

Tamlihah, Tamlihah, Abd. Mukhid, and Hilmi Qosim Mubah. "Implementasi Manajemen Kurikulum Pesantren Dalam Membentuk Karakter Mandiri Santri Di Pondok Pesantren Nurus Sibyan Ambat Tlanakan Pamekasan.” Re-JIEM (Research Journal of Islamic Education Management) 3, no. 1 (2020): 96. https://doi.org/10.19105/rejiem.v3i1.2957.

Yusuf, Syamsu. Psikologi Perkembangan Anak Dan Remaja. Bandung: Remaja Rosdakarya, 2006. 